\title{
Editorial: Songs of Innocence
}

Where is it now, the glory and the dream? Wordsworth was neither the first nor the last to notice that growing older may involve a loss as well as a gain in knowledge of the world and life and time. The innocent eye may see some things to which it will be blinded by experience. Herodotus was consciously or unconsciously making a strong claim for his own people when he reported the remark of the Egyptian sage to Solon: 'You Greeks are always children'. Plato's doctrine of Recollection was one of the sources of Wordsworth's 'Ode: Intimations of Immortality from Recollections of Early Childhood'. Professor R. M. Hare in 'Philosophical Discoveries' (Mind, 1960) offers what he describes as a demythologized version of Plato's doctrine of anamnesis:

It is an example of the perceptive genius of that great logician, that in spite of being altogether at sea concerning the source of our philosophical knowledge; and in spite of the fact that his use of the material mode of speech misled him as to the status of the analyses he was looking forthat in spite of all this he spotted the very close logical analogies between philosophical discoveries and remembering. He was wrong in supposing that we are remembering something that we learnt in a former life-just as more recent mythologists have been wrong in thinking that we are discerning the structure of some entities called 'facts'. What we are actually remembering is what we learnt on our mothers' knees, and cannot remember learning.

Many other poets and Platonists could be quoted to similar effect. We are assured by texts of scripture that the same applies to philosophy of life as to the more technical philosophy that Professor Hare had in mind. Except we become as little children, there are many mysteries of living and learning into which we shall not enter. The Child's Conception of the World by Jean Piaget is accordingly an absorbing source book for the philosopher threatened by disabling maturity.

Professor Gareth B. Matthews has taken the whole subject further. Many readers of this journal will know his essay 'On Talking Philosophy with Children' in Communication and Understanding, the Royal Institute Lecture Volume for $1975-76$. Material from it has now been incorporated in a larger work, Philosophy and the Young Child, recently published by Harvard University Press. Professor Matthews 'first became interested in the philosophical thought of young children by worrying how to teach introductory courses in philosophy to college students'. By showing them that many of them had already done philosophy as children he sought 


\section{Editorial}

to revive in them a recognition of what a natural activity it is. The book is the fruit of the research and teaching to which he was led from this starting point. His sources include Plato and Piaget (but not Wordsworth). He also sees what rich resources are stocked in the work of Lewis Carroll, A. A. Milne, L. Frank Baum (author of The Wonderful Wizard of $\mathrm{Oz}$ ) and others whose imagination remained childlike amid the perils of sophistication. But most of his best material is drawn from conversations with his own and other children and from anecdotes supplied by students and colleagues. Six-year-old Tim propounds a Cartesian question and offers a Malcolmian answer: 'Well, I don't think everything is a dream, 'cause in a dream people wouldn't go round asking if it was a dream'. When eightyear-old John asks 'Why don't I see you double because I have two eyes?', his father uses the reliable old philosophical method of answering a question with a question: 'Are you surprised you don't hear double?' John at once picks up the technique and replies: 'What is hearing double?'

The risks are precocity and preciousness. The best children's writers are those who are best at preserving the naïveté to whose sophistication their work is a tribute. The occupational self-consciousness of the philosopher is a handicap in such an enterprise. Professor Matthews has taken great care, but some of his students seem to have shown more zeal than judgment. Any parent, even a philosopher, can sympathise with the mother of seven-year-old Michael. She finally announced that enough was enough after her son had spent three hours being interviewed on God, evil and infinity.

The fattest worm in the bud lurks on the back cover, where one of the well-deserved tributes to Professor Matthews' enterprise comes from the Director of the Institute for the Advancement of Philosophy for Children. Now nothing can save us from a Yournal of Children's Philosophy. 